\title{
Comprehensive evaluation of the Siberian gene pool of common bean (Phaseolus vulgaris L.) in the conditions of Western Siberia
}

\author{
O.E. Yakubenko ${ }^{1,2 *}$, O.V. Parkina ${ }^{2}$ \\ 1 Institute of Cytology of Genetics, SB RAS, Novosibirsk, Russia \\ ${ }^{2}$ Novosibirsk State Agrarian University, Russia
}

DOI 10.18699/ICG-PlantGen2019-71

Abstract: Evaluation of the gene pool of common beans for the main economically valuable traits in the conditions of Western Siberia was conducted. The object of research is 57 varieties of common bean vegetables and grain of various ecological and geographical origin. According to the results of research, genetic sources of economically valuable traits were identified: high yield, quality of the beans (color, shape of the bean), presence or absence of the parchment layer. The result of the research identified the most valuable common bean samples adapted to the conditions of Western Siberia.

Key words: common bean; Phaseolus vulgaris L.; agronomic traits.

\section{Introduction}

Common bean (Phaseolus vulgaris L.) is the most important food culture in the genus Phaseolus of the family Leguminosae, which includes more than 200 species and only 20 species are cultural, the others are wild. Functional products have a special value for human food. Cereals and legumes are of special interest. Common bean has a unique and balanced composition of seeds and green beans with high protein, vitamins, macro- and micro- element content. In many countries, common bean is the primary source of protein; common bean occupies the second place in area among grain crops in the world. In the Siberian region, vegetable beans are grown mainly in home gardens. One of the reasons for their low-scale production is the absence of high-yielding varieties consistent with industrial cultivation technology.

A feature of common beans is that among the most important food crops it has a high polymorphism of morphological characteristics and properties. Of great importance for creation of new varieties is the use of collection material of different ecological and geographic origin.

It is necessary to study and to replenish the gene pool of common bean for selection of source and donors of importance traits.

The purpose of the study is to evaluate of the gene pool and to select genetic sources of common bean by primary agronomic traits in the conditions of Western Siberia.

\section{Materials and methods}

For complex evaluation of variety samples of common bean, a collection nursery was laid on the experimental field of the training and production farm in the Novosibirsk SAU. A plot is located in Novosibirsk on the right bank of the Ob River.

The soil of the experimental plot is gray forest heavy loamy on carbon-free heavy loam. The climate is continental.

From 1997 to the present in the base department of breeding, genetics and forestry of Novosibirsk SAU, more than 150 breeding samples with various ecological and geographic origin were studied. The studied samples of a variety of vegetable bean are divided by origin as follows: most (51\%) are introduced, including $47 \%$ of European origin and $4 \%$ of
Asian origin, the others are of hybrid origin, obtained using the ecological-geographical principle. Breeding samples studied by primary agriculture traits: the length of the vegetation period, the nature of growth (type of growth), plant height and attachment of the lower beans, the shape, length and color of the beans, the presence of the parchment layer and fiber in the seam.

Object of research: 23 variety samples of vegetable bean and 34 samples of haricot bean. Standard for vegetable bean is the variety Solnishko of Siberian selection, standard for haricot bean is the variety Zolotistaya. Sowing was conducted in the second decade of May. Planting was by hand, by the wide-row method with a $70-\mathrm{cm}$ row spacing. Seeding quantity was 22 pieces $/ \mathrm{m}^{2}$.

Accounting of the yield of green beans was carried out in dynamics every 7 days three times during the growing season.

Observations, accountings and analyses were conducted using "Guidelines for the study of the collection of grain legumes", "Guidelines for the study of samples of the world bean collection" and "Guidelines for the use of the classifier Phaseolus L. (Haricot)".

Harvesting was conducted separately, the plants were uprooted and placed in rolls. After ripening, beans were threshed.

\section{Results and discussion}

To meet the needs of the consumer and the manufacturer, the breeder must consider the following parameters: plants in the form of a bush must be compact, with a height of attachment of the lower bean not less than $12 \mathrm{~cm}$, green or yellow color of the beans. All studied varieties had a compact deterministic bush form. Plant height varied from 37 ('Daria') to $51 \mathrm{~cm}$ ('Olhensia'). The height of attachment of the lower bean varied from 8 ('Cinderella') to $16 \mathrm{~cm}$ ('Yellow Octave'). More than $85 \%$ of the samples had a bottom bean attachment height of more than $12 \mathrm{~cm}$. The coefficient of variation is $12.6 \%$. Based on the duration of the vegetation period, the varieties were divided into 4 groups of ripeness (early maturing, $7 \%$ of which can be distinguished very early: 'Ukrainka', 'G32', 'Nika', 'Sekunda', 'Maxi'; 43 \%, medium early: 'Sunny', 'G135'; $37 \%$, middle ripening: 'Viola', 'G171'; and $13 \%$, 
late ripening). The color of beans is of commercial interest for the producers.

The results of the study show that five samples had yellow beans, one purple beans, and the others green beans. The crosssectional shape of the studied samples was observed rounded in $47 \%$ of the samples, flat-round in $40 \%$ of the varieties and flat in $13 \%$. The length of the beans varied from 8.2 ('Slav') to $17.9 \mathrm{~cm}$ ('Purple baby'). More than $80 \%$ of the samples match the production requirements for the optimal length of a bean of $10-13 \mathrm{~cm}$. The coefficient of variation was $19.1 \%$.

The largest quantities of formed beans was in 'Sunray' (31 pcs), while 'Magura' and 'Delinel' (17 pcs) had the smallest quantities of formed beans. The coefficient of variation was $32.9 \%$. The samples of 'Sekunda' ( $9.8 \mathrm{~g}$ ) had the largest mass of 1 bean, the lowest one was with 'Ukrainka' (4.6 g). The coefficient of variation was $17.3 \%$. The average number of formed beans per plant was 21 and the average weight of 1 bean per plant was $6.2 \mathrm{~g}$.

The most productive was the sample of 'Sunray' ( $3.3 \mathrm{~kg} /$ $\left.\mathrm{m}^{2}\right)$, and the low productive was 'Magura' $\left(1.9 \mathrm{~kg} / \mathrm{m}^{2}\right)$. The coefficient of variation was $27.5 \%$.

The results of the investigation show that the number of seeds per plant varied from 26 ('Ruby') to 44 pieces ('Bomba'). The coefficient of variation is $18.4 \%$. The seed mass per plant varied from $12.8 \mathrm{~g}$ ('Golden') to $23.6 \mathrm{~g}$ ('Red-motley'), the coefficient of variation was $19.4 \%$. The mass of 1000 seeds varied from $183.65 \mathrm{~g}$ (Sinelnikovskaya) to $662.45 \mathrm{~g}$ ('Zusha motley'). The coefficient of variation is $35.6 \%$. The seed yield varied from $62.7 \mathrm{~g} / \mathrm{m}^{2}$ ('Motolskaya white') to $281.64 \mathrm{~g} / \mathrm{m}^{2}$ ('Motley Romano'). The coefficient of variation is $23.8 \%$. The average yield by the varieties studied was $191.1 \mathrm{~g} / \mathrm{m}^{2}$.

\section{Conclusions}

On the base of results of a complex assessment of vegetable beans, samples were selected for the main economic and agriculture traits:

1. By precocity: early maturing: Magura, Daria, Orbel yellow; mid-season: Ukrainka, Sekunda, Slavyanka, Jubilee, Golden Mountain, Olhensia, Rocquentcant, Delinel.

2. By the height of attachment of the lower bean (more than $12 \mathrm{~cm}$ ): Magura, Daria, Orbel yellow, Sekunda, Slavyanka, Jubilee, Golden Mountain, Olhensia, Rocquentcant, Delinel, Purple Baby.
3. By the quantities and weight of the beans from the plant samples: Sekunda, Sunray, Morena, Jubilee, Rocquentcant.

4. By the technical quality of green pods: 17 varieties had green beans and 5, yellow beans; the absence of fiber in the seam: all the studied samples, except for Moscow greenhand, Morena, Magura.

5 . By the yield of beans: more than $2.7 \mathrm{~kg} / \mathrm{m}^{2}$ : Golden Mountain, Rocquentcant, Sunray, Daria, Sekunda, Morena, Jubilee.

6. For a set of economically valuable traits, samples identified were Rocquentcant, Daria, Sekunda.

7. For a set of economically valuable traits: samples of grain beans: Stringless, Black, Zusha motley, Oran, Rubin and Sinelnikovskaya, which can be recommended for inclusion in breeding programs and for cultivation in the conditions of Western Siberia.

The creation of varieties with a complex of certain breeding traits based on the available breeding samples of the Siberian gene pool for specific soil and climatic conditions will ensure high rates of productivity and quality.

\section{References}

Agoyi E.E., Mohammed K.E., Odong T.L., Tumuhairwe J.B., Chigeza G., Tukamuhabwa P. Mode of inheritance of promiscuous nodulation and combining abilities in soybean genotypes. Int. J. Agron. Agric. Res. 2016;9:73-82.

Belarmino D. Inheritance of resistance to common bacterial blight (Xanthomonas campestris pv. phaseoli) disease and yield of common bean. Master thesis. Makerere University, 2015.

Bernado R. Breeding for quantitative traits in plants. Stemma Press, Minnesota, 2010.

Guidelines for the study of the collection of grain legumes. SPb, 1974. $60 \mathrm{p}$.

Guidelines for the study of samples of the world collection of beans St. Petersburg, 1987. 60 p.

Singh S.P., Miklas P.N. Breeding common bean for resistance to common blight: A review. Crop Sci. 2015;55:971-984.

Trindade R.D.S., Rodrigues R., do Amaral Jùnior A.T., Gonçalves L.S.A., Viana J.M.S., Sudré C.P. Combining ability for common bacterial blight resistance in snap and dry bean (Phaseolus vulgaris L.). Acta Sci. Agron. 2014;37:37-43.

Zapata M., Beaver J.S., Porch T.G. Dominant gene for common bean resistance to common bacterial blight caused by Xanthomonas axonopodis pv. phaseoli. Euphytica. 2011;179:373-382.

Conflict of interest. The authors declare no conflict of interest. 